\title{
Compound Eye Fine Structure in Paralomis multispina Benedict, an Anomuran Half-Crab From 1200 m Depth (Crustacea; Decapoda; Anomura)
}

\author{
EISUKE EGUCHI ${ }^{1}$, MARI DEZAWA ${ }^{2}$, AND V. BENNO MEYER-ROCHOW ${ }^{3}$ \\ ${ }^{1}$ Department of Biology, Yokohama City University, 22-2 Seto, Kanazawa-ku, Yokohama 236, \\ Japan, from Japan Marine Science and Technology Center (JAMSTEC), Natsushima-cho, \\ Yokosuka, 237, Japan; ${ }^{2}$ Department of Anatomy, School of Medicine, Chiba University, Inohana, \\ Chuo-ku, Chiba 260, Japan; and ${ }^{3}$ Department of Biology (Section Animal Physiology), \\ University of Oulu, SF-90570 Oulu, Finland
}

\begin{abstract}
Fully grown, unsexed specimens of the anomuran half-crab Paralomis multispina Benedict were obtained from a depth of $1200 \mathrm{~m}$, and the eyes of three individuals were prepared for light and electron microscopy. In their outer appearance the compound eyes of Paralomis resemble those of common shallow-water half-crabs (e.g., Petrolisthes), but facets in Paralomis were about 3 times larger in diameter (i.e., $60 \mu \mathrm{m}$ ) and at least twice as long. Interommatidial angles ranged from $3^{\circ}$ to $5^{\circ}$. The proximal width of the crystalline cone in Paralomis was 10 times that of its equivalent in the Petrolisthes eye, and the rhabdom-although only twice as long - had a radius that was 7 times greater distally and 4 times greater proximally. A clear-zone between cones and rhabdom was not developed, and cross sections of crystalline cones revealed rounded rather than square profiles. A distal retinula cell (R8) was absent, and all regular retinula cells $(\mathrm{R} 1-\mathrm{R} 7)$ protruded microvilli of about $0.11 \mu \mathrm{m}$ diameter in many (and not only two) directions. A maximum rhabdom occupation ratio of $85 \%$ was found in the Paralomis retinula, whereas in the shallow-water half-crabs the comparable figure was $35 \%$. Paralomis featured a wide, rhabdomless space between basement membrane and proximal rhabdom ends; the space was occupied by reflecting cells. Primary screening pigment cells and their dark granules were present; secondary screening pigment cells, however, were replaced
\end{abstract}

Received 19 June 1996; accepted 18 November 1996. by reflecting cells. The anatomical modifications in the Paralomis eye are consistent with habitat-related adaptations seen in the eyes of other benthic and slow-moving deep-water crustaceans, but not with those of euphausiids. We conclude that the eye of Paralomis functions as an apposition eye, designed to maximize photon capture, especially from point sources (i.e., bioluminescence) rather than extended sources. We estimate that the Paralomis eye is at least 150 times more sensitive to light than the eye of shallow-water Petrolisthes.

\section{Introduction}

Animals that live in or colonize greater oceanic depths face three major physical challenges (Marshall, 1957; Thorson, 1972): (a) atmospheric pressure increases by 1 with every $10 \mathrm{~m}$ of water; (b) ambient light levels become progressively reduced, and the spectral composition of the downwelling light changes as depth increases; and (c) the temperature of the water falls as the distance to the surface increases, except in the polar oceans (where bottom temperatures may actually lie a few degrees above those of the surface) and near hydrothermal vents.

The eyes of animals are usually attuned to the photic conditions under which they operate (Forward et al., 1988), but environmental temperature and pressure also influence certain structural and functional parameters of photoreception through their effects on membrane fatty acid content and composition (Cossins and Macdonald, 1989; Sebert et al., 1992; Kashiwagi et al., 1996). Based 
on a number of light microscopical (Beddard, 1890; Welsh and Chace, 1937, 1938; Zharkova, 1970, 1975; Bursey, 1975) and electron microscopical studies of deep-water crustacean eyes (Elofsson and Hallberg, 1977; Ball, 1977; Hallberg, 1977; Meyer-Rochow and Walsh, 1977, 1978; Hallberg et al., 1980; Gaten et al., 1992; Gaten, 1994; Nuckley et al., 1996), certain general trends concerning their anatomy and performance in relation to depth have become apparent.

Bath pelagic and benthic species of depths exceeding $1000 \mathrm{~m}$ usually exhibit small and degenerate eyes (similar to those of species known from marine caves (MeyerRochow and Juberthie-Jupeau, 1987). Crustaceans inhabiting zones above $1000 \mathrm{~m}$, on the other hand, frequently possess adaptations such as enlarged ommatidia, more voluminous rhabdoms, presence of retinal reflectors, etc., to improve the efficiency of photon capture. Often such adaptations enhance overall sensitivity at the expense of acuity, but in cases where acuity apparently suffers little degradation, regional eye modifications and special optical designs may be employed as, for instance, in the Euphausiaceae (Land et al., 1979; Hiller-Adams and Case, 1984). Most euphausiids, however, are luminescent and thus not necessarily representative of other groups of crustaceans. For that reason and the fact that few species of deep-sea crustaceans have had their photoreceptors studied, we decided to examine the eyes of the anomuran decapod half-crab Paralomis multispina from a depth of $1200 \mathrm{~m}$ and compare them with those of shallow-water anomurans investigated earlier (Eguchi et al., 1982; Meyer-Rochow et al., 1990; Gaten, 1994).

\section{Materials and Methods}

Several unsexed specimens of Paralomis multispina Benedict (Decapoda, Anomura, Galatheoidea) with carapace widths ranging from 5 to $11 \mathrm{~cm}$ and maximum body lengths (from head to tail) of $11.5 \mathrm{~cm}$ (Fig. 1a) were obtained in March 1992. Collections were made from the "Hatsushima seep" (Ohta et al., 1987) at a depth of $1200 \mathrm{~m}$ about $5 \mathrm{~km}$ off Hatsushima Island in Sagami Bay (Shizuoka Prefecture, Japan) during a cruise of the manned research submersible Shinkai 2000 (JAMSTEC). The half-crabs themselves are not considered to be thermophilic, although they occurred in association with the giant clam Calyptogena soyae, vestimentiferan tube worms, gastropods, and polychaetes (Hashimoto et al., 1987) in an area that was characterized by an extremely high methane content. The half-crabs were picked up from the seafloor with remotely controlled artificial arms and put in a basket attached to the outside of the submersible. It took about $1 \mathrm{~h}$ for the submersible, with the collected animals, to reach the surface at about $1700 \mathrm{~h}$.
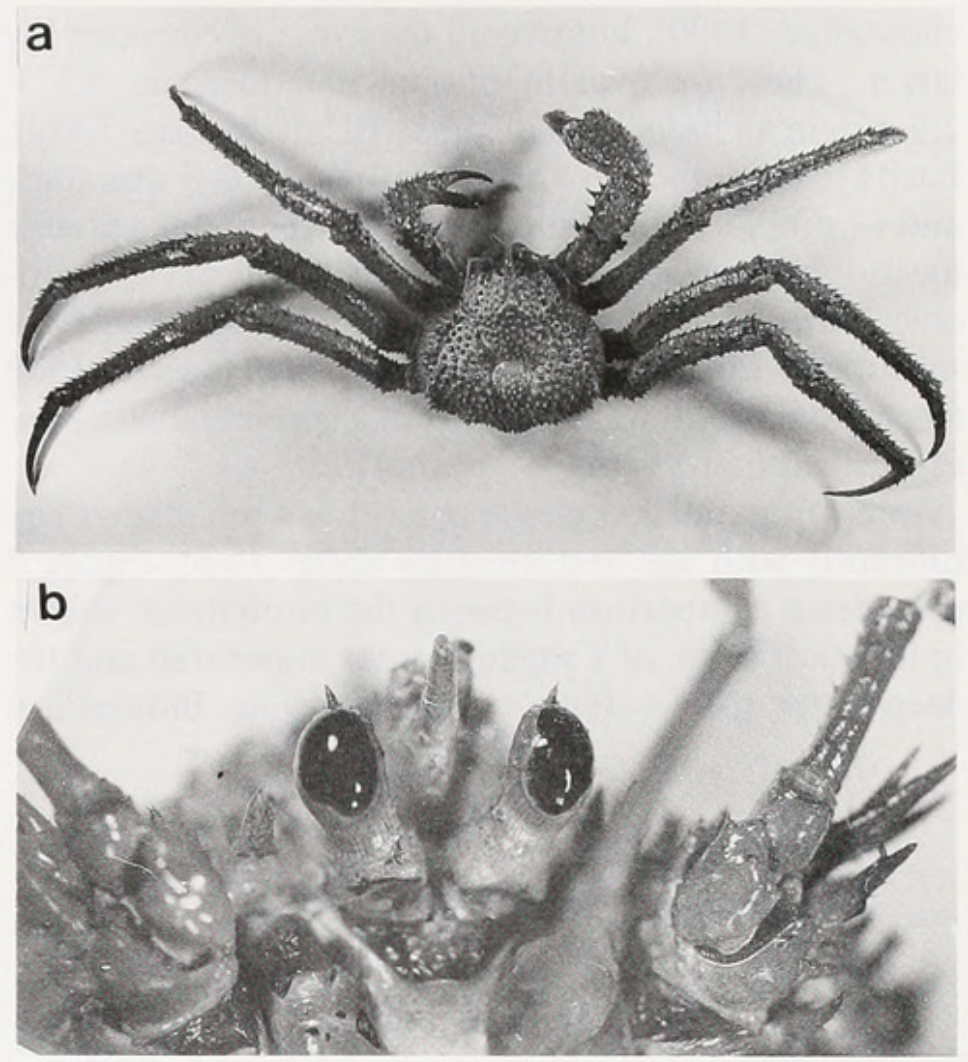

Figure 1. Photographs of Paralomis multispina. (a) Dorsal view of specimen with carapace width of $11 \mathrm{~cm}$ and legs $30 \mathrm{~cm}$ long. (b) Closeup of head region with pair of eyestalks and black shiny eyes, each measuring about $4 \mathrm{~mm}$ in length in this specimen.

During capture, the animals were exposed to 10,000 20,000 lux bright sunlight for about $20 \mathrm{~min}$, but immediately after they had been hauled on board the mothership Natsushima, the compound eyes of three individuals were fixed for $12 \mathrm{~h}$ at $4^{\circ} \mathrm{C}$ in $2 \%$ glutaraldehyde and $2 \%$ paraformaldehyde solution, buffered to a $\mathrm{pH}$ of 7.3 with $0.1 \mathrm{M}$ cacodylate buffer. The dissections were carried out under dim red light to minimize further exposure to light and structural damage ( $c f$. Meyer-Rochow, 1994). After a brief wash in buffer, the specimens were postfixed for $2 \mathrm{~h}$ in $2 \% \mathrm{OsO}_{4}$ solution, using the same buffer as before, and dehydrated in a graded series of acetone before being embedded in Epon 812. Ultrathin sections, cut with a diamond knife, were picked up on uncoated 200-mesh copper grids and stained with uranyl acetate and lead citrate for a few minutes. Observations were carried out under a JEM 1200EX transmission electron microscope, operated at $80 \mathrm{kV}$.

\section{Results}

In their external appearance the compound eyes of the deep-sea anomuran Paralomis multispina (Fig. 1b) resemble those of other common anomuran shore-crabs (e.g., genus Petrolisthes: Eguchi et al., 1982; Meyer-Ro- 
chow et al., 1990), but overall the eyes are considerably larger. They are oval in outline and measure $3.5 \times$ $2.5 \mathrm{~mm}$ in an individual of about $10 \mathrm{~cm}$ carapace width. Each eye sits at the tip of an eyestalk that is $4-5 \mathrm{~mm}$ thick and $12 \mathrm{~mm}$ long; thus inter-eye distances and the precise location of the eyes in space are to a certain extent variable. Ommatidial numbers increase with age: whereas a specimen with a carapace length of $5 \mathrm{~cm}$ has about 1500 facets, some 2400 were counted in a specimen with a carapace width of $10 \mathrm{~cm}$.

Interommatidial angles apparently do not change significantly with age and measure about $3^{\circ}-5^{\circ}$. Figure 2 provides a comparison between the ommatidia, shown in identical scale, of a shallow-water anomuran and the deep-water species Paralomis multispina. Biometrical

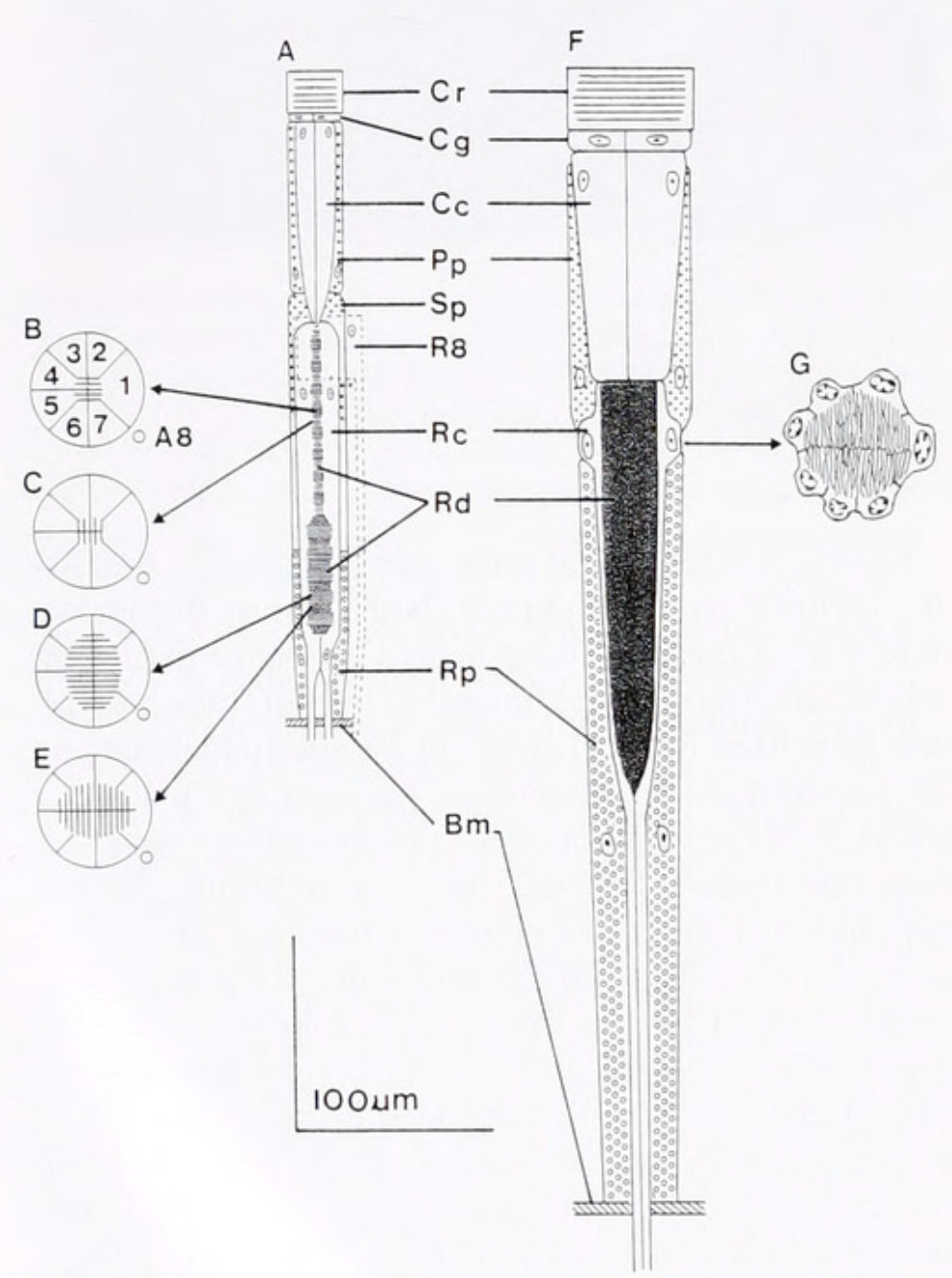

Figure 2. D

(A-E), found in sin

in the deep-sea at the

cell $\mathrm{R} 8 ; \mathrm{Bm}=$ basemer

neagenous cell; $\mathrm{Cr}=\mathrm{co}$

rhabdom; Rp ment cell. (A) longitudinal section; ( $B, C)$ cross sections at the level of
two adjacent bands in the distal layers of the rhabdom; (D, E) cross
sections of two adjacent bands in the proximal rhabdom layers. (F)
longitudinal scction; $(G)$ cross section at distal rhabdom layers. ment cell. (A) longitudinal section; ( $B, C$ ) cross sections at the level of
sections of two adjacent bands in the proximal rhabdom layers. (F)
longitudinal scction; $(G)$ cross section at distal rhabdom layers. ment cell. (A) longitudinal section; ( $B, C$ ) cross sections at the level of
sections of two adjacent bands in the proximal rhabdom layers. (F)
longitudinal scction; $(G)$ cross section at distal rhabdom layers. ment cell. (A) longitudinal section; ( $B, C)$ cross sections at the level of
sections of two adjacent bands in the proximal rhabdom layers. (F)
longitudinal section; $(G)$ cross section at distal rhabdom layers. ment cell. (A) longitudinal section; ( $B, C$ ) cross sections at the level of
sections of two adjacent bands in the proximal rhabdom layers. (F)
longitudinal scction; $(G)$ cross section at distal rhabdom layers. ment cell. (A) longitudinal section; ( $, C, C)$ cross sections at the level of
two adjacent bands in the distal layers of the rhabdom; (D, E) cross
sections of two adjacent bands in the proximal rhabdom layers. (F)
longitudinal scction; $(G)$ cross section at distal rhabdom layers. ment cell. (A) longitudinal section; (B, C) cross sections at the level of
two adjacent bands in the distal layers of the rhabdom; (D, E) cross
longitudinal scction; $(G)$ cross section at distal rhabdom layers.

omparable ommatidia of Petrolisthes sp. and Paralomis multispina $(\mathrm{F}, \mathrm{G})$, found lative scale. $\mathrm{A} 8=$ axon of distal retinula mbrane; $\mathrm{Cc}=$ crystalline cone; $\mathrm{Cg}=$ cordistal retinula cell; $\mathrm{Rc}=$ retinula data of the constituent parts of one representative central ommatidium of the compound eye of the two crustaceans are given in Table I. From Figure 2 and Table I it is evident that the ommatidium of the deep-sea half-crab is much larger than that of the shallow-water species, even if differences in body size are taken into consideration.

\section{Dioptric apparatus}

A single facet of the eye of Paralomis is about 3 times larger in diameter and has a corneal lens that is 1.8 times thicker than that of a comparable shallow-water Petrolisthes. No significant difference between the two types could be detected, however, in the $200 \mu \mathrm{m}$ thick periodic layers, revealed in longitudinal sections of the cornea along the optic axis. Two corneagenous cells, not noticeably different from those of Petrolisthes or any other decapod crustacean, occupied the space between cornea and cone.

The crystalline cone of Paralomis tapered only very gently and retained a much wider proximal diameter (Fig. 3a) than that of Petrolisthes. Whereas in Petrolisthes, cross sections through distal and central regions of the cone displayed square profiles and a content of electron-dense material, sections through the cone of Paralomis at corresponding levels exhibited rather circular outlines and a content of much looser consistency (Fig. 3b). When related to overall ommatidial length, the dioptric apparatus in the eye of Paralomis (though greatly enlarged in diameter) occupied significantly less space than the equivalent structure in the eye of the shallow-water Petrolisthes.

\section{Retinula and rhabdom}

In the eyes of other anomuran species-for example, Petrolisthes spp. (Eguchi et al., 1982; Meyer-Rochow et al., 1990) and Munida spp. (Bursey, 1975; Gaten, 1994) - a distal retinula cell (R8) with four cytoplasmic lobes occupies the tier between the crystalline cone and the seven regular retinular cells, but in Paralomis an ommatidial retinula is composed of only seven regular cells (1-7) and lacks the distal eighth cell. The distal end of the rhabdom is thus made up of seven regular retinula cells, which are in contact with the proximal end of the crystalline cone. It is in this region that the mottled retinula cell nuclei, with a maximum diameter of $7.5 \mu \mathrm{m}$, can be found.

The rhabdoms in Paralomis are extraordinarily well developed and occupy up to $85 \%$ of the available cytoplasmic space in the distal and central regions of the retinula (Fig. 4). The estimated membrane surface of an ommatidial rhabdom of Paralomis $\left(231 \times 10^{4}\right)$, calcu- 
Table I

Comparison of biometrical data (in $\mu \mathrm{m}$ ) of ommatidia in the shallow-water Petrolisthes sp. and the deep-sea Paralomis multispina

\begin{tabular}{|c|c|c|c|c|}
\hline & Petrolisthes & Paralomis & Para/Petro & Remarks \\
\hline \multicolumn{5}{|l|}{ Cornea } \\
\hline diameter & 21 & 60 & 2.9 & \\
\hline thickness & 16 & 28 & 1.8 & \\
\hline \multicolumn{5}{|l|}{ Crystalline cone } \\
\hline distal diameter & 20 & 56 & 2.8 & length of a square side \\
\hline prox. diameter & 4 & 40 & 10.0 & \\
\hline length & 110 & 110 & 1.0 & \\
\hline \multicolumn{5}{|l|}{ Ommatidial retinula } \\
\hline length & 60 & 390 & 2.6 & \\
\hline diameter & 20 & 40 & 2.0 & \\
\hline \multicolumn{5}{|l|}{ Rhabdom } \\
\hline diameter at nuclear layer & 3.5 & 25 & 7.1 & \\
\hline diameter at proximal layer & $3 \times 8^{*}$ & 18 & 3.7 & ${ }^{*}$ rectangular \\
\hline length & 50 & 210 & 1.9 & \\
\hline thickness of one band & 7 & $4-7$ & $0.6-1.0$ & \\
\hline diameter of one microvillus & 0.08 & 0.11 & 1.4 & \\
\hline area of rhabdom membrane & $8.5 \times 10^{4}$ & $231 \times 10^{4}$ & 27.2 & total surface of microvilli/ommatidium \\
\hline \multicolumn{5}{|l|}{ Rhabdom occupation ratio (\%) } \\
\hline distal and central region & 12 & 85 & 6.3 & \\
\hline proximal region & 35 & 45 & 1.3 & \\
\hline Distance from rhabdom end to BM & 12 & 180 & 15.0 & \\
\hline Interommatidial angle & $4-6^{\circ}$ & $3-5^{\circ}$ & ca. 0.9 & \\
\hline Sensitivity & 0.23 & 34.7 & 151 & relat. sensitivities (after Land, 1981) \\
\hline
\end{tabular}

lated from the data in Table I, is about 27 times larger than that of Petrolisthes $\left(8.5 \times 10^{4}\right)$. Another comparison could be made with Limulus, which-even though it is not a crustacean-has a compound eye (Fahrenbach, 1969) superficially similar to that of Paralomis, but with rhabdom occupation ratios generally lower than $10 \%$. On the other hand, the hydrothermal vent shrimp Rimicaris exoculata occurs in a habitat similar to that of Paralomis, but its eye is highly aberrant, with volume densities of rhabdoms reaching 70\%-80\% (O'Neill et al.,
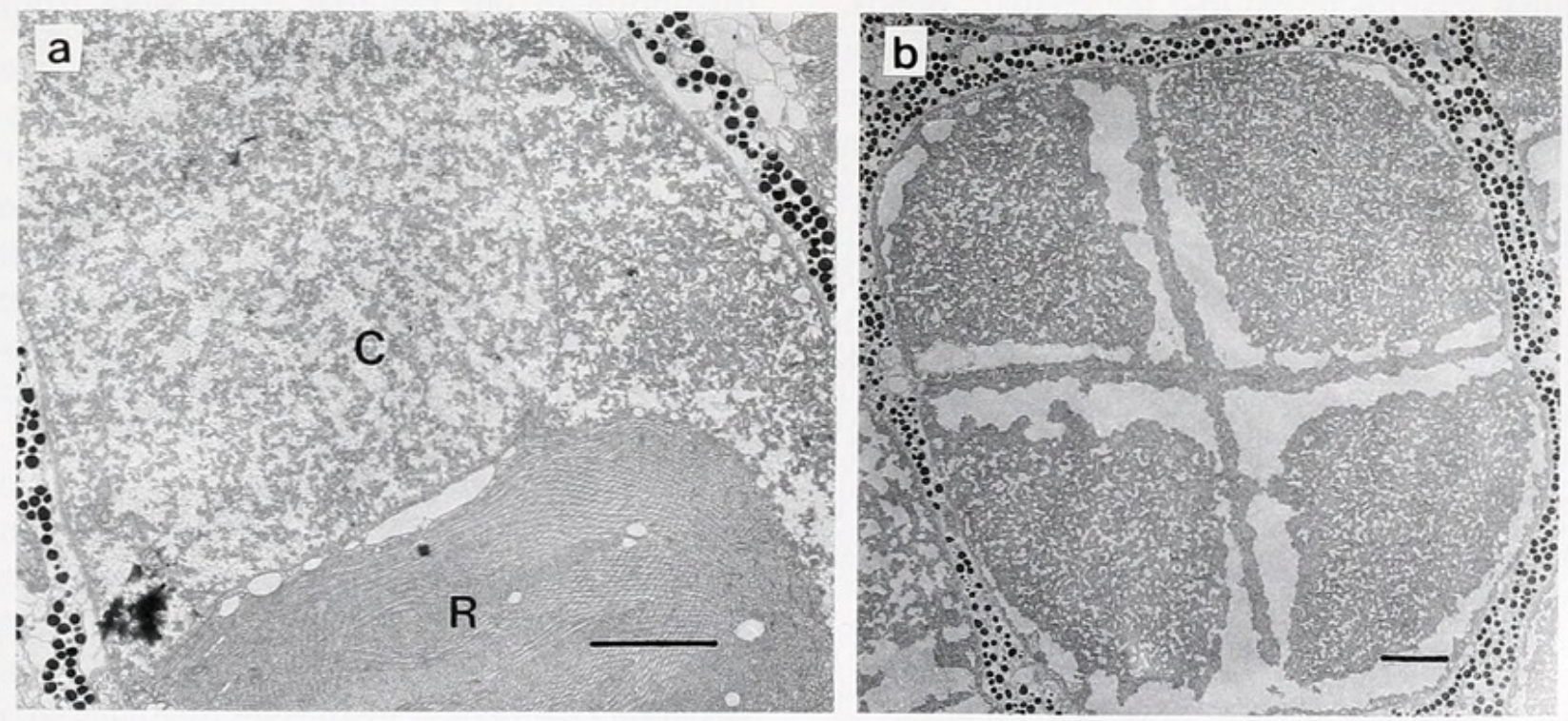

Figure 3. The deep-sea half-crab Paralomis multispina. (a) Longitudinal section through the proximal region of the crystalline cone and the distal tip. $\mathrm{C}=$ crystalline cone; $\mathrm{R}=$ rhabdom. Scale bar $=5 \mu \mathrm{m}$. (b) Cross section through proximal part of crystalline cone with its four components. Numerous screening pigment granules surround the crystalline cone. Scale bar $=5 \mu \mathrm{m}$. 


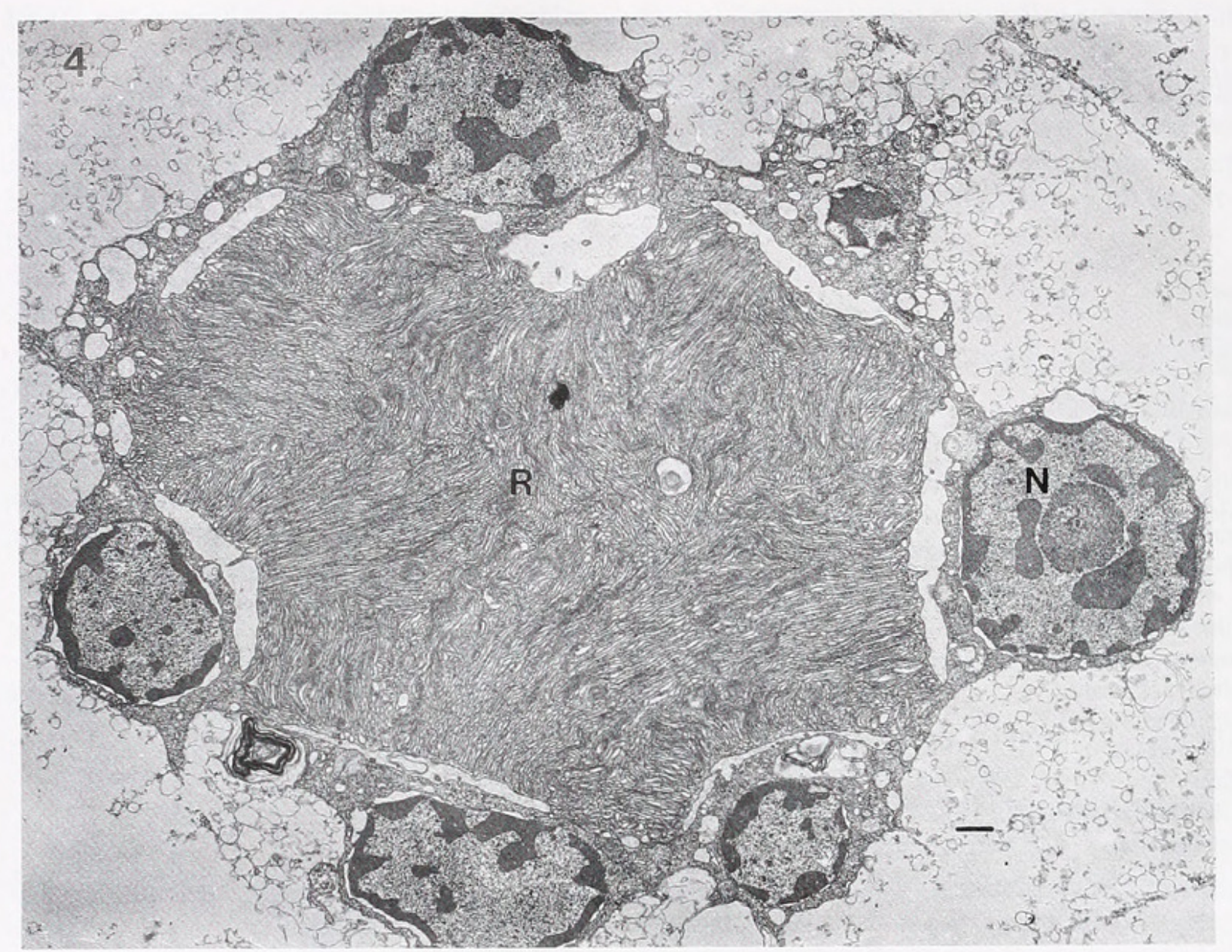

Figure 4. Cross section of rhabdom at the retinula cell nuclear layer. Almost the entire cytoplasmic space of the retinula cells is occupied by the rhabdomeres. $\mathrm{N}=$ nucleus of retinula cell; $\mathrm{R}=$ rhabdom. Scale bar $=1 \mu \mathrm{m}$.

1995). The retinula cells do not form proper rhabdoms in the proximal region; instead they gradually turn into slender axonal processes (Fig. 5).

Longitudinal sections reveal that the regular "bands," so typical for the rhabdoms of other decapods (including those of the shallow-water anomuran species), are almost lost in Paralomis and are replaced by microvilli running in many directions. This gives the rhabdom a somewhat irregular, disorderly appearance. Individual microvilli in Paralomis (Fig. 6) were thicker $(0.11 \mu \mathrm{m})$ than those of fully grown shallow-water Petrolisthes $(0.08 \mu \mathrm{m}$ : Eguchi et al., 1982; Meyer-Rochow and Reid, 1996). This difference has to be interpreted with caution, since it is known from other crustacean eyes (e.g., Orchomene sp.: MeyerRochow, 1981; Mysis relicta: Lindström et al., 1988) that

abdom microvilli have a tendency to swell and increase imeter when suddenly exposed to very bright light.

re-filament, usually identifiable in the lumen of a abdom microvillus of the crustacean eye, was most st or fragmented into smaller pieces (Fig. 7). Some habdom microvilli exhibited flattened or swoller structures in the place where core-filaments with their as ci ted side-arms should have been. Since core- filaments and their associated side-arms in compound eyes are fragile and easily destroyed by irradiation with bright light (Blest et al., 1982; Tsukita et al., 1988), their disruption in our material could stem from the brief exposure to sunlight during capture.

\section{Screening pigment}

The eye of Paralomis lacks secondary pigment cells; two primary pigment cells are found around the crystalline cones and contain spherical electron-opaque pigment grains of about $0.4 \mu \mathrm{m}$ in diameter (Fig. 3a). The density of these granules seems not to differ from that of granules in the shallow-water half-crabs, but screening pigment granules in the retinula cells are far less numerous in Paralomis. In place of secondary pigment cells are an unknown number of cells presumed to contain reflecting granules.

\section{Reflecting pigment}

The distance between the proximal end of the rhabdom and the basement membrane of an ommatidium is relatively short in Petrolisthes and other shallow-water 

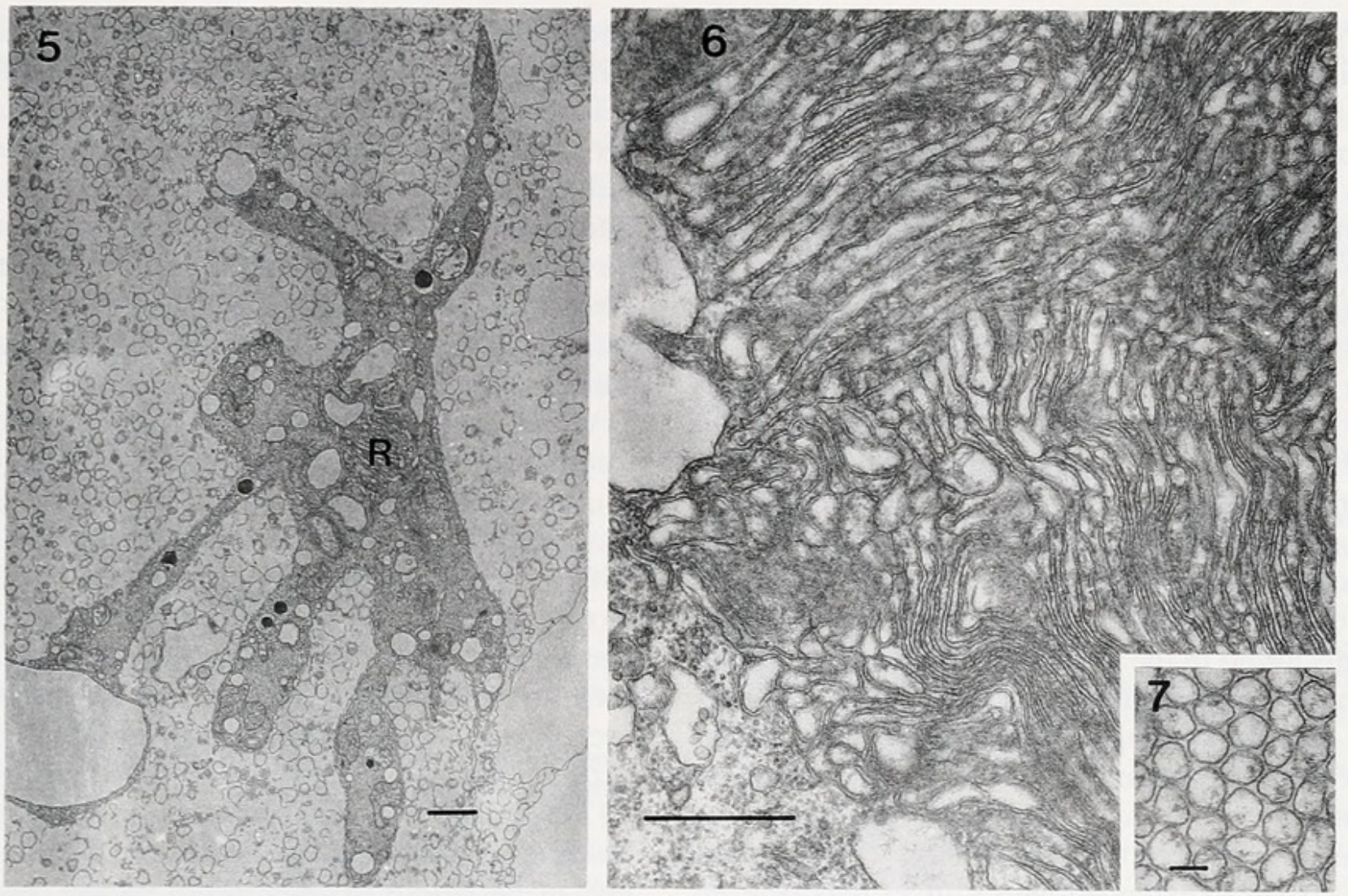

Figure 5. Cross section through proximal retinal layer. A small rhabdom $(R)$ is seen at the center of a cluster of seven retinula cells. A few scattered screening pigment granules are visible in some of the retinula cells. Well-developed reflecting pigment cells fill the interommatidial spaces. Scale bar $=1 \mu \mathrm{m}$.

Figure 6. Cross section through a segment of a retinula cell demonstrating the multidirectional orientation of microvilli in the rhabdom. Scale bar $=1 \mu \mathrm{m}$.

Figure 7. Higher magnification of transversely cut microvilli of the rhabdom. Note that core-filaments are lost in some of the microvilli. Scale bar $=0.1 \mu \mathrm{m}$.

decapods. In Paralomis, however, this same distance is strikingly long $(\mathrm{ca} .180 \mu \mathrm{m})$. In the proximal layer, the retinula cells become slender as shown in Figure 5. The space thus made available is filled with enormously developed cells containing large amounts of reflecting pigments. The extensions of the reflecting pigment cells, which are easily identifiable by their innumerable 0.3 $\mu \mathrm{m}$-wide vesicles, penetrate between the retinula cells of individual ommatidial units, thus apparently increasing their effectiveness in reflecting light towards the more distally placed rhabdom.

\section{Discussion}

Eguchi et al. (1982) suggested that anomuran halfcrabs of the superfamily Galatheoidea possess reflecting superposition eyes. Research by Meyer-Rochow et al. (1990) on the galatheid Petrolisthes elongatus and by Gaten (1994) on Munida rugosa lent further support to this notion, but specified that this was true only for the darkadapted eye; in the light-adapted state apposition optics were used. It is generally assumed that superposition eyes are more useful than apposition eyes in dim light, for the former are typical of many nocturnal crustaceans and deep-sea forms.

It is, therefore, a little surprising to find that the eye of the deep-sea anomuran galatheid Paralomis multispina (a) lacks a wide clear-zone, which is normally considered a prerequisite for any form of superposition vision (Land, 1981), and (b) possesses roundish rather than regular, square cones, which are an essential requirement for reflecting superposition (Land, 1976; Vogt, 1980). The species does, however, exhibit other kinds of modifications that are more in keeping with adaptations to an extremely dim environment: compared with the shallow-water half-crabs of the genus Petrolisthes (Eguchi et al., 1982; Meyer-Rochow et al., 1990), in Paralomis the corneal diameter is three times greater, and cone as well as rhabdom diameters are even more enlarged (Table I). The reflecting tapetum on the proximal side of the retinula is massively developed, and it is evident that the eye is designed to maximize photon capture. The fine-struc- 
tural disruptions and larger diameters of the rhabdom microvilli seen in Paralomis are almost identical to those reported from the eyes of deep-water amphipods from the Antarctic (Meyer-Rochow, 1981) and are most likely caused by the exposure to bright light during capture. Indirectly the disruptions thus point to a high absolute sensitivity to light, but at the same time they obscure signs for or against membrane shedding ( $c f$. Chamberlain and Barlow, 1984).

On the basis of the definition that Land (1981) provided for "absolute sensitivity," we calculated sensitivities of light-adapted eyes of Paralomis and those of shallow-water Petrolisthes: the eye of Paralomis was 150 times more sensitive. The comparison is based on the assumptions that the extinction coefficient $(\mathrm{k})$ is the same for the two species and that the types and densities of pigments found in the rhabdoms are identical ( $c f$. discussion in Ziedins and Meyer-Rochow, 1990). If one assumes a superior photopigment content in the darkadapted Paralomis eye and considers thermal noise reduction at low environmental temperatures (Aho et al., 1988), the overall sensitivity advantage of Paralomis over Petrolisthes to extended light sources may be even higher.

If the lack of a clear-zone is real and not artifactual (clear-zones in the superposition eyes of deep-sea decapods can easily collapse and, on account of their fragility and delicateness, may remain undetected as shown by Nilsson, 1990), the closer approximation of the massively developed rhabdom to the much wider dioptric elements, in combination with the backing of a tapetum from behind, could be interpreted as an adaptation to improve sensitivity, especially to point sources. The shortening of both cornea and cone, relative to the overall length of one ommatidium, and the loss of the orderly arrangement of microvilli in the rhabdom also point toward an adaptation to minimize photon loss and maximize photon capture (Laughlin et al., 1975). The considerably greater rhabdom-occupation ratio in the eye of Paralomis as compared with the shallow-water species not only allows more photopigment molecules to be packed into the visual membranes, but also indicates low energy demand and slow cellular metabolism, both adaptations that are extremely useful in the deep-sea environment (Elofsson and Hallberg, 1977).

In the shallow-water Petrolisthes elongatus the eye enlarges as the half-crab grows; ommatidia are added and sensitivity to both extended and point sources increases. $P$. elongatus uses vision to detect and approach hiding places (Meyer-Rochow and Meha, 1994). Since signs of eye regression in adult Paralomis are missing, we must assume that the general growth pattern resembles that of Petrolisthes. This, however, raises the question of what
Paralomis could possibly see at a depth of $1200 \mathrm{~m}$, the "limit" beyond which sunlight can no longer be detected (Clarke and Kelly, 1964). Biological light sources, however, abound at this depth (Omori, 1974), and it may well be in the interest of a benthic, sedentary detritus and filter feeder to notice them. Any visual signal adult Paralomis could possibly be interested in would almost never come from below, and this could explain the lack of regional eye specializations seen in so many mesopelagic shrimps (Gaten et al., 1992).

We know nothing about the spectral sensitivity of Paralomis, but the visual pigments of eight other anomuran species all exhibit a single absorption peak in the bluegreen region of the spectrum (Cronin and Forward, 1988). Ziedins and Meyer-Rochow (1990) electrophysiologically measured spectral sensitivity peaks of darkand light-adapted eyes of $P$. elongatus and also found them to lie in the bluegreen part of the spectrum. Since even the eyes of the hydrothermal vent species Rimicaris exoculata, which are strongly modified morphologically (O’Neill et al., 1995), possess a sensitivity peak in the bluegreen (Johnson et al., 1995), we do not expect the eyes of Paralomis to differ in this respect. However, the lack of secondary screening pigments and retinula cell 8 in Paralomis suggests that the eye of $M$. rugosa, for example, is less well adapted to the greatest depth of its range (shallow water down to $1250 \mathrm{~m}$ : Gaten, 1994) than that of Paralomis. M. rugosa appears to be a relative "newcomer" to the deep-sea, while Paralomis has been exploiting that habitat for a longer evolutionary period. How much longer is hard to say, but Nuckley et al. (1996) speculate that a hydrothermal vent shrimp with modified eyes may have "migrated from the surface possibly in the last 5,000-10,000 years" and over that period evolved its present eye morphology.

In conclusion, the hypertrophied rhabdoms in the eye of Paralomis, the loss of the orderly microvillus arrangement, the reduction of the cytoplasmic component of the retinula cells, the massively developed layer of reflecting vesicles in the proximal half of the retinula, and (considering overall ommatidial length) the relative shortening of the dioptric elements coincident with greatly enlarged diameters in the eye of Paralomis are all consistent with depth-related adaptations seen also in the eyes of deepsea mysids (Elofsson and Hallberg, 1977), amphipods (Hallberg et al., 1980; Meyer-Rochow et al., 1991), and to some extent other benthic decapods (Hiller-Adams and Case, 1985) and mesopelagic shrimps (Gaten et al., 1992). However, the eyes of deep-water euphausiids (Hiller-Adams and Case, 1988) are least similar to those of Paralomis and this, we believe, has to do with (a) the widespread ability of euphausiids to produce light, (b) the greater mobility and pelagic lifestyles of euphausiids, 
and (c) the longer evolutionary period euphausiids have had to adapt their photoreceptors to the deep-sea environment.

\section{Acknowledgments}

We thank the Shinkai 2000 operation team and the Japan Marine Science and Technology Center (JAMSTEC) (Natsushimacho, Yokosuka, Japan) for their kind offer to assist in the procurement of the material. We also wish to acknowledge that through the constructive criticism of two anonymous referees we were able to improve the paper.

\section{Literature Cited}

Aho, A. C., K. O. Donner, C. Hyden, L. O. Larsen, and T. Reuter. 1988. Low retinal noise in animals with low body temperatures allows high visual sensitivity. Nature 334: 348-350.

Ball, E. E. 1977. Fine structure of the compound eyes of the midwater amphipod Phronima in relation to behaviour and habitat. Tissue Cell 9: 251-536.

Beddard, F. E. 1980. On the minute structure of the eye in some shallow-water and deep-sea species of the isopod genus Acturus. Proc. Zool. Soc. Lond. 26: 365-375.

Blest, D., S. Stowe, and W. Eddy. 1982. Cytoskeleton in rhabdomeral microvilli of blowflies. Cell Tissue Res. 223: 553-573.

Bursey, C. R. 1975. The microanatomy of the compound eye of Munida irrasa (Decapoda: Galatheidae). Cell Tissue Res. 160: 505514

Chamberlain, S. C., and R. B. Barlow, Jr. 1984. Transient membrane shedding in Limulus photoreceptors: control mechanisms under natural lighting. J. Neurosci. 4: 2792-2810.

Clarke, G. L., and M. G. Kelly. 1964. Variation in transparency and in bioluminescence on longitudinal transects in the western Indian Ocean. Bull. Inst. Oceanogr. (Monaco) 64: 1-20.

Cossins, A. R., and A. G. Macdonald. 1989. The adaptation of biological membranes to temperature and pressure: fish from the deep and cold. J. Bioenerg. Biomembr. 21: 115-135.

Cronin, T. W., and R. B. Forward. 1988. The visual pigments of crabs. I. spectral characteristics. J. Comp. Physiol. A 162: 463-478.

Eguchi, E., T. Goto, and T. H. Waterman. 1982. Unorthodox pattern of microvilli and intercellular junctions in regular retinular cells of the porcellanid crab Petrolisthes. Cell Tissue Res. 222: 493-513.

Elofsson, R., and E. Hallberg. 1977. Compound eyes of some deepsea and fiord mysid crustaceans. Acta Zool. (Stockh.) 58: 169-177.

Fahrenbach, W.H. 1969. The morphology of the eyes of LimulusII. Ommatidia of the compound eye. Z. Zellforsch. 93: 451-483.

Forward, R. B., T. W. Cronin, and J. K. Douglass. 1988. The visual pigments of crabs. II. environmental adaptations. J. Comp. Physiol. A 162: 479-490.

Gaten, E. 1994. Geometrical optics of a galatheid compound eye. $J$. Comp. Physiol. A 175: 749-759.

Gaten, E., P. M. J. Shelton, and P. J. Herring. 1992. Regional morphological variations in the compound eyes of certain mesopelagic shrimps in relation to their habitat. J. Mar. Biol. Assoc. UK 72: 6175.

Hallberg, E. 1977. The fine structure of the compound eyes of mysids (Crustacea: Mysidacea). Cell Tissue Res. 184: 45-65.

Hallberg, E., H. Nilsson, and R. Elofsson. 1980. Classification of am- phipod compound eyes - the fine structure of the ommatidial units (Crustacea, Amphipoda). Zoomorphology 94: 279-306.

Hashimoto, J., T. Tanaka, S. Matsuzawa, and H. Hotta. 1987. Surveys of the deep-sea communities dominated by the giant clam $\mathrm{Ca}$ lyptogena soyae along the slope foot of Hatsushima Island, Sagami Bay. JAMSTECTR Deepsea Res. 3: 37-51.

Hiller-Adams, P., and J. F. Case. 1984. Optical parameters of euphausiid eyes as a function of habitat depth. J. Comp. Physiol. 154: 307-318.

Hiller-Adams, P., and J. F. Case. 1985. Optical parameters of the eyes of some benthic decapods as a function of habitat depth. Zoomorphology 105: 108-113.

Hiller-Adams, P., and J. F. Case. 1988. Eye size of pelagic crustaceans as a function of habitat depth and possession of photophores. Vision Res. 28: 667-680.

Johnson, M. L., P. M. J. Shelton, P. J. Herring, and S. Gardner. 1995. Spectral responses from the dorsal organ of a juvenile Rimicaris exoculata from the TAG-hydrothermal vent site. Bridge Newslett. 8: $38-42$.

Kashiwagi, T., V. B. Meyer-Rochow, K. Nishimura, and E. Eguchi. 1996. Fatty acid composition and ultrastructure of photoreceptive membranes in the crayfish Procambarus clarkii under conditions of thermal and photic stress. J. Comp. Physiol. B. In press.

Land, M. F. 1976. Superposition images are formed by reflection in the eyes of some oceanic decapod Crustacea. Nature 263: 764-765.

Land, M. F. 1981. Optics and vision in invertebrates. Pp. 471-492 in Vision in Invertebrates (Handbook of Sensory Physiology, Vol. VII/ 6B), H. Autrum, ed. Springer, New York.

Land, M. F., F. A. Burton, and V. B. Meyer-Rochow. 1979. The optical geometry of euphausiid eyes. J. Comp. Physiol. 130: 49-62.

Laughlin, S. B., R. Menzel, and A. W. Snyder. 1975. Membranes, dichroism and receptor sensitivity. Pp. 237-262 in Photoreceptor Optics, A. W. Snyder and R. Menzel, eds. Springer, New York.

Lindström, M., H. Nilsson, and V. B. Meyer-Rochow. 1988. Recovery from light-induced sensitivity loss in the eye of the crustacean Mysis relicta in relation to temperature: a study of ERG-determined $\mathrm{V} / \log \mathrm{I}$ relationships and morphology at $4^{\circ} \mathrm{C}$ and $14^{\circ} \mathrm{C}$. Zool. Sci. 5: 743-757.

Marshall, N. B. 1957. Tiefseebiologie. VEB, Jena, Germany.

Meyer-Rochow, V. B. 1981. The eye of Orchomene sp. cf. O. rossi, an amphipod living under the Ross Ice Shelf (Antarctica). Proc. R. Soc. Lond. B Biol. Sci. 212: 93-111

Meyer-Rochow, V. B. 1994. Light-induced damage to photoreceptors of spiny lobsters and other crustaceans. Crustaceana 67: 97111

Meyer-Rochow, V. B., and J. Juberthie-Jupeau. 1987. An electron microscope study of the eye of the cave mysid Heteromysoides cotti from the Island of Lanzarote (Canary Isl.). Stygologia 3: 24-34.

Meyer-Rochow, V. B., and W. P. Meha. 1994. Tidal rhythm and the role of vision in shelter-seeking behaviour of the half-crab Petrolisthes elongatus (Crustacea; Anomura). J. R. Soc. NZ 24: 423428.

Meyer-Rochow, V. B., and W. A. Reid. 1996. Does age matter in studying the crustacean eye? J. Comp. Physiol. B: In press.

Meyer-Rochow, V. B., and S. Walsh. 1977. The eyes of mesopelagic crustaceans I. Gennadas sp. (Penaeidae). Cell Tissue Res. 186: 87101

Meyer-Rochow, V. B., and S. Walsh. 1978. The eyes of mesopelagic crustaceans III. Thysanopoda tricuspidata (Euphausiaceae). Cell Tissue Res. 195: 59-79

Meyer-Rochow, V. B., D. Towers, and I. Ziedins. 1990. Growth patterns in the eye of Petrolisthes elongatus (Crustacea; Decapoda; Anomura). Exp. Biol. 48: 329-340. 
Meyer-Rochow, V. B., H.Stephan, and S. D. Moro. 1991. Morphological and anatomical observations on the hairy eyes of males and females of the marine amphipod Dulichia porrecta (Crustacea, Amphipoda, Podoceridae). Boll. Zool. 58: 59-69.

Nilsson, D.-E. 1990. Three unexpected cases of refracting superposition eyes in crustaceans. J. Comp. Physiol. A 167: 71-78.

Nuckley, D. J., R. N. Jinks, B.-A. Battelle, E. D. Herzog, L. Kass, G. H. Renninger, and S. C. Chamberlain. 1996. Retinal anatomy of a new species of bresiliid shrimp from a hydrothermal vent field on the mid-atlantic ridge. Biol. Bull. 190: 98-110.

Ohta, S., H. Sakai, A. Taira, K. Ohwada, T. Ishii, M. Maeda, K. Fujioka, T. Saino, K. Kogure, T. Gamo, Y. Shirayama, T. Furuta, T. Ishizuka, K. Endow, T. Sumi, H. Hotta, J. Hashimoto, N. Handa, T. Masuzawa, and M. Horikoshi. 1987. Report on multi-disciplinary investigations of the Calyptogena communities at the Hatsushima site. JAMSTECTR Deepsea Res. 3: 52-65.

Omori, M. 1974. The biology of pelagic shrimps. Pp. 233-324 in Advances in Marine Biology. F. S. Russel and M. Yonge, eds. Academic Press, New York.

O’Neill, P. J., R. N. Jinks, E. D. Herzog, B.-A. Battelle, L. Kass, G. H. Renninger, and S. C. Chamberlain. 1995. The morphology of the dorsal eye of the hydrothermal vent shrimp, Rimicaris exoculata. Visual Neurosci. 12: 861-875.
Sebert, P., B. Simon, and L. Barthelemy. 1992. Fluidite membranaire et allometrie: interet ecophysiologique. Bull. Soc. Ecophysiol. 17: $115-120$.

Thorson, G. 1972. Erforschung des Meeres-eine Bestandsaufnahme. Kindler, Munich.

Tsukita, S., S. Tsukita, and G. Matsumoto. 1988. Light induced structural changes of cytoskeleton in squid photoreceptor microvilli detected by rapid-freeze method. J. Cell Biol. 106: 1151-1160.

Vogt, K. 1980. Die Spiegeloptik des Flusskrebsauges. J. Comp. Physiol. 135: 1-19.

Welsh, J. H., and F. A. Chace. 1937. Eyes of deep-sea crustaceans I. Acanthephyridae. Biol. Bull. 72: 57-74.

Welsh, J. H., and F. A. Chace. 1938. Eyes of deep-sea crustaceans II. Sergestidae. Biol. Bull. 74: 364-375.

Zharkova, I. S. 1970. Reduction of the organs of vision in deep-sea mysids. Zool. Zh. 49: 685-693.

Zharkova, I. S. 1975. Reduction of organs of sight in deep-water Isopoda, Amphipoda, and Decapoda. Zool. Zh. 54: 200-208.

Ziedins, I., and V. B. Meyer-Rochow. 1990. ERG-determined spectral and absolute sensitivities in relation to age and size in the halfcrab Petrolisthes elongatus (Crustacea; Decapoda; Anomura). Exp. Biol. 48: 319-328. 


\section{$2 \mathrm{BHL}$ Biodiversity Heritage Library}

Eguchi, Eisuke, Dezawa, M, and Meyer-Rochow, V. B. 1997. "Compound Eye Fine Structure in Paralomis multispina Benedict, an Anomuran Half-Crab From 1200 m Depth (Crustacea; Decapoda; Anomura)." The Biological bulletin 192, 300-308. https://doi.org/10.2307/1542723.

View This Item Online: https://www.biodiversitylibrary.org/item/17361

DOI: https://doi.org/10.2307/1542723

Permalink: https://www.biodiversitylibrary.org/partpdf/32088

\section{Holding Institution}

MBLWHOI Library

\section{Sponsored by}

MBLWHOI Library

\section{Copyright \& Reuse}

Copyright Status: In copyright. Digitized with the permission of the rights holder.

License: http://creativecommons.org/licenses/by-nc-sa/3.0/

Rights: https://biodiversitylibrary.org/permissions

This document was created from content at the Biodiversity Heritage Library, the world's largest open access digital library for biodiversity literature and archives. Visit BHL at https://www.biodiversitylibrary.org. 